\title{
The lebercilin-like protein is embedded in a ciliary protein network and is preferentially expressed in motile cilia
}

\author{
DA Mans ${ }^{1 *}$, KLM Coene ${ }^{1}$, K Boldt ${ }^{2}$, IJC Lamers ${ }^{1}$, J van Reeuwijk', NT Loges ${ }^{3}$, E Bolat ${ }^{1}$, L Franke ${ }^{4}$, L Hetterschijt ${ }^{1}$, \\ SJF Letteboer ${ }^{1}$, TA Peters ${ }^{5,6}$, H Omran $^{3}$, FPM Cremers ${ }^{1}$, M Ueffing ${ }^{2,7}$, R Roepman ${ }^{1}$
}

From First International Cilia in Development and Disease Scientific Conference (2012)

London, UK. 16-18 May 2012

Mutations in LCA5 are causative for Leber congenital amaurosis, a severe hereditary retinal dystrophy in humans. Lebercilin, encoded by $L C A 5$, localizes to connecting cilia of photoreceptor cells in the retina and specifically interacts with the intraflagellar transport (IFT) machinery. Bioinformatic analysis has identified lebercilin-like protein, previously known as C21orf13, as a lebercilin homolog in humans. In this study, we have characterized the molecular properties of lebercilin-like protein by defining the lebercilin-like interactome and assessing its (sub)cellular localization in ciliated cells. We show that lebercilin-like protein is embedded in a ciliary protein network and specifically localizes at the basal body and ciliary axoneme of ciliated cells, like lebercilin. mRNA expression studies indicate that lebercilin-like protein is preferentially expressed in tissues featuring motile cilia and/or flagella. Based on these data and bioinformatic co-expression profiling, we suggest that $L C A 5 L$ is a likely candidate gene for motile ciliopathies such as Primary Ciliary Dyskinesia (PCD).

\section{Author details}

'Department of Human Genetics, Nijmegen Centre for Molecular Life Sciences, Radboud University Nijmegen Medical Centre, the Netherlands. ${ }^{2}$ Division of Experimental Ophthalmology and Medical Proteome Center, Center of Ophthalmology, University of Tübingen, Germany.

${ }^{3}$ Children's Department, University Hospital Münster, Germany.

${ }^{4}$ Department of Genetics, University Medical Center Groningen and

University of Groningen, Germany. ${ }^{5}$ Department of Otorhinolaryngology, Nijmegen Centre for Molecular Life Sciences, Radboud University Nijmegen Medical Centre, the Netherlands. ${ }^{6}$ Donders Institute for Brain, Cognition and Behaviour, the Netherlands. ${ }^{7}$ Department of Protein Science, Helmholtz

\footnotetext{
* Correspondence: D.Mans@antrg.umcn.nl

'Department of Human Genetics, Nijmegen Centre for Molecular Life Sciences, Radboud University Nijmegen Medical Centre, the Netherlands Full list of author information is available at the end of the article
}

Zentrum München, German Research Center for Environmental Health, Germany.

Published: 16 November 2012

\section{doi:10.1186/2046-2530-1-S1-P93}

Cite this article as: Mans et al:: The lebercilin-like protein is embedded in a ciliary protein network and is preferentially expressed in motile cilia. Cilia 2012 1(Suppl 1):P93.
Submit your next manuscript to BioMed Central and take full advantage of:

- Convenient online submission

- Thorough peer review

- No space constraints or color figure charges

- Immediate publication on acceptance

- Inclusion in PubMed, CAS, Scopus and Google Scholar

- Research which is freely available for redistribution

Submit your manuscript at www.biomedcentral.com/submit
() Biomed Central 